\title{
How ENSO affects maize yields in China: understanding the impact mechanisms using a process-based crop model
}

\author{
Jiabing Shuai, ${ }^{\text {a,b }}$ Zhao Zhang, ${ }^{\text {a Fulu Tao }}{ }^{\mathrm{c} *}$ and Peijun Shi ${ }^{\text {a* }}$ \\ a State Key Laboratory of Earth Surface Processes and Resource Ecology/Academy of Disaster Reduction and Emergency Management, Beijing \\ Normal University, China \\ ${ }^{\mathrm{b}}$ Agricultural Reinsurance Department, China Property and Casualty Reinsurance Company Ltd, Beijing, China \\ ${ }^{\mathrm{c}}$ Institute of Geographical Sciences and Natural Resources Research, Chinese Academy of Sciences, Beijing, China
}

\begin{abstract}
The El Niño Southern Oscillation (ENSO) is one of the main factors influencing global climate variability and consequently has a major effect on crop yield variability. However, most studies have been based on statistical approaches, which make it difficult to discover the underlying impact mechanisms. Here, using process-based crop model Model to Capture the Crop-Weather relationship over a Large Area (MCWLA)-Maize, we found a consistent spatial pattern of maize yield variability in association with ENSO between MCWLA-Maize model outputs and observations. During El Niño years, most areas of China, especially in the north, experience a yield increase, whereas some areas in the south have a decrease in yields. During La Niña years, there is an obvious decline in yields, mainly in the north and northeast, and a general increase in the south. In-depth analyses suggest that precipitation $P$ rather than temperature $T$ and solar radiation $S$ during the maize growing season is the main cause of ENSO-induced maize yield variability in northern and northeastern China. Although a $2^{\circ} \mathrm{C}$ change of $T$ can affect maize yields more than a $20 \%$ change of $P$, greater changes of $P$ contribute more to maize yield variability during ENSO years. In general, maize yields in drier regions are much more sensitive to $P$ variability than those in wetter areas. All changes in meteorological variables, including $T, P, S$, and vapour pressure deficit $\left(\mathrm{V}_{\mathrm{PD}}\right)$ during ENSO years, affect yield variability mainly through their effects on water stress. Our results suggest that more effective agricultural information can be provided to government decision makers and farmers by developing a food security warning system based on the MCWLA-Maize model and ENSO forecast information.
\end{abstract}

KEY WORDS ENSO; maize yields; water stress; China; climate variability; crop model

Received 22 November 2013; Revised 31 January 2015; Accepted 1 April 2015

\section{Introduction}

Maize is one of the main essential cereals in China, comprising 33.5 million hectare of sown area and 193 million metric tons of production in 2011 (National Bureau of Statistics of China, 2013). China accounts for $21.7 \%$ of global maize production and was the second largest producing country behind the United States in 2011 (Food and Agriculture Organization, FAO: http://faostat.fao.org/site/567/default.aspx\#ancor). However, maize yields are subject to large interannual variability caused by climate variation (Tao et al., 2004). This variability directly affects crop growth, development, and yields, and also indirectly influences pest dynamics and fertilizer efficiency (Thompson, 1986; Lima et al., 1999; Almaraz et al., 2008; Chen et al., 2011).

The El Niño Southern Oscillation (ENSO), which refers to fluctuations of both sea surface temperature (SST) in

\footnotetext{
* Correspondence to: F. Tao, Institute of Geographical Sciences and Natural Resources Research, Chinese Academy of Sciences, Beijing 100101, China. E-mail: taofl@igsnrr.ac.cn; or P. Shi, State Key Laboratory of Earth Surface Processes and Resource Ecology/Academy of Disaster Reduction and Emergency Management, Beijing Normal University, Beijing 100875, China. E-mail: spj@bnu.edu.cn
}

the tropical Pacific and sea level pressure in the southern Pacific (Southern Oscillation Index, SOI), is well-known as one of the strongest drivers of global interannual climate variability (Diaz and Markgraf, 2000). The entire atmospheric circulation responds dramatically to the more slowly varying SST in the tropical Pacific. The warm pools of seawater, low-level westerlies, attendant tropical convection, and low-pressure centre shift from the western Pacific to the central or eastern Pacific at the height of El Niño events (Chu, 2004; Sun and Frank, 2010). Consequently, climate in many regions all over the world, especially in the Pacific Rim, is influenced to varying degrees (Kenyon and Hegerl, 2008; Alexander et al., 2009). The climate of China, one of the countries in the Pacific Rim, is also strongly affected by ENSO (Chang et al., 2000a, 2000b; Wang et al., 2000; Wang and Zhang, 2002; Wu et al., 2003; Feng and Li, 2011). Generally, there will be greater than average precipitation in most regions of China during summers in the decaying stage of El Niño years and less than average in years following La Niña years (Huang and $\mathrm{Wu}, 1989$ ). In some extreme events, ENSO-related changes to climate have caused major meteorological disasters (Dilley and Heyman, 1995). For instance, during 1997/1998, 
the strongest El Niño event in the 20th century, China suffered massive flooding of 25 million hectares of farmland, which caused over 20 billion USD in estimated damages (Sun and Zhou, 2008). In the 2010/2011 La Niña year, China experienced two consecutive seasonal droughts (winter and spring) that, according to the Ministry of Land and Resources of China, affected 20\% of farmland and $35 \%$ of all wheat crops in eight provinces, including Henan, Shandong, and Hebei (See XINHUA news: http://www.webcitation.org/5wVDplgm4). All these facts emphasize the need for studies that can provide sound climate and crop production forecast information for crop management. With the development of climate models, ENSO prediction skill is maturing and ENSO information can be accurately predicted at least 1 year in advance (Cane, 2005; Ludescher et al., 2013). Providing such information early enough to adjust critical agricultural decisions offers significant potential to enhance the efficiency of agricultural management and food and livelihood security.

Therefore, the relationship between ENSO climate variability and agricultural production has been a major concern (Hansen et al., 1998; Hansen et al., 1999; Podestá et al., 1999; Tao et al., 2004; Hansen et al., 2006). As early as the 1980s, correlation between SST and crop production in the United States (Handler, 1984) and Austria (Nicholls, 1985) was identified, evidencing the potential for translating ENSO information into agricultural terms. When the predictability of ENSO was demonstrated in the late 1980s and early 1990s, much more attention was given to issues of ENSO and agriculture (Cane et al., 1994; Phillips et al., 1998; Phillips et al., 1999). There have been many studies on this topic worldwide (e.g. Garcia et al., 2010; Royce et al., 2011; Paz et al., 2012). In China, for example, Tao et al. (2004) investigated the statistical relationship of three staple crops in the country with ENSO phases and the Asian monsoon, using data from seven major provinces. They showed large annual crop yield variability to be associated with ENSO and the Asian monsoon. Based on Tao et al. (2004), Shuai et al. (2013) studied the spatial pattern of ENSO impacts on staple crop yields during ENSO decaying stages, suggesting that the mechanism of ENSO impact on crop yield varies with location and crop variety.

However, most studies have been based on statistical approaches (e.g. Hansen et al., 1998, 1999; Tao et al., 2004), which make it difficult to identify underlying mechanisms of ENSO-induced climate variability effects on crop yield. Although historical maize yields can be easily obtained, they are limited to certain locations or regions. Also, information on maize water use during growing season is not available and can only be estimated using historical weather data and empirical approaches. The lack of simultaneous availability of historical maize yield and water use data limits their use in studies related to climate variability such as ENSO. However, crop yield and water use as a function of crop management and environmental factors, such as weather and soil, can be simulated by different crop models. These models can be useful tools for understanding mechanisms of spatial and temporal yield variability related to ENSO.

In several studies, crop models (e.g. Crop Environment Resource Synthesis model (CERES)) have been used to address the impact of ENSO on crop yield only at certain sites (e.g. Phillips et al., 1998; Hansen et al., 2006) because of the point-based nature of the models. Nonetheless, ENSO-induced climate variability and its impacts on crop yield generally occur at large scale. Crop models that account for key impact mechanisms of climate variability and are accurate over a large area should be used. In this study, we use a large-scale crop model, the Model to Capture the Crop-Weather relationship over a Large Area (MCWLA)-Maize. This model is applied to assess mechanisms of maize yield variability in association with ENSO in China and to suggest possible adaptation measurements to cope with climate variability in ENSO years. MCWLA-Maize has been used to investigate the impacts of climate variability on crop productivity in major maize production areas in China (Tao et al., 2009a, 2009b) and other regions (Bassu et al., 2014), as well as to quantify the contributions of various options for adapting to climate change (Tao and Zhang, 2010). Studies have shown that MCWLA-Maize has good performance in simulating the response of crop growth and yield to climate variability.

\section{Materials and data}

\subsection{Study area}

Maize is planted extensively and in a variety of climates in our study area, which is mainland China. This area extends from $18^{\circ}$ to $53^{\circ} \mathrm{N}$ and $74^{\circ}$ to $134^{\circ} \mathrm{E}$. Maize cultivation areas were divided into six sub-regions: North China spring maize (R1), Huang-Huai-Hai Plain summer maize (R2), Southwest China maize (R3), South China maize (R4), Northwest China maize (R5), and Tibet maize (R6) (Tong, 1992). R1 in northeastern China and R2 in northern China are the two major maize production areas in the country (Figure 1). Spring maize dominates in R1 with approximate growing season from April through October, and summer maize in R2 with approximate growing season from May through October. R5 and R6 are not included in this study because maize cultivation fractions in the two regions are small. Most areas in R1 (main1) and R2 (main2) were selected as the two major areas (Figure 2) for in-depth analyses.

\subsection{MCWLA-Maize crop model}

Details of MCWLA-Maize model development, parameter optimization, and uncertainty analyses are found in Tao et al. (2009a, 2009b). Briefly, MCWLA-Maize simulates crop growth and development with a daily time-step. The model is designed to investigate the impacts of weather and climate variability on crop growth, development, and productivity at large scale. Growing degree days are drivers for the processes of canopy development, flowering, and maturity. Daily growth of crop leaf area is simulated by heat-dependent potential growth 


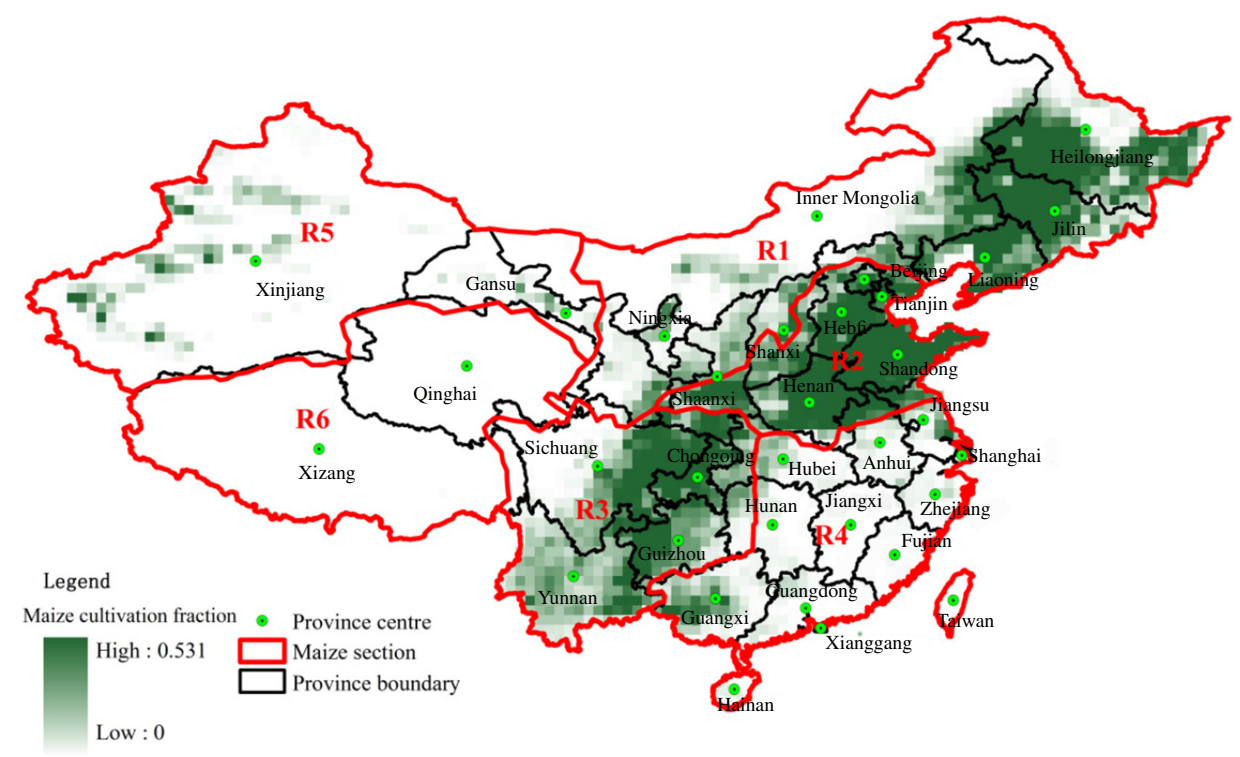

Figure 1. The cultivation fraction (originally from Qiu et al., 2003) and agroecological zones (Tong, 1992) for maize in China. There are totally six agroecological zones: North China spring maize area (R1), Huang-Huai-Hai plain summer maize area (R2), Southwest China maize area (R3), South China maize area (R4), Northwest China maize area (R5), and Tibet maize area (R6).

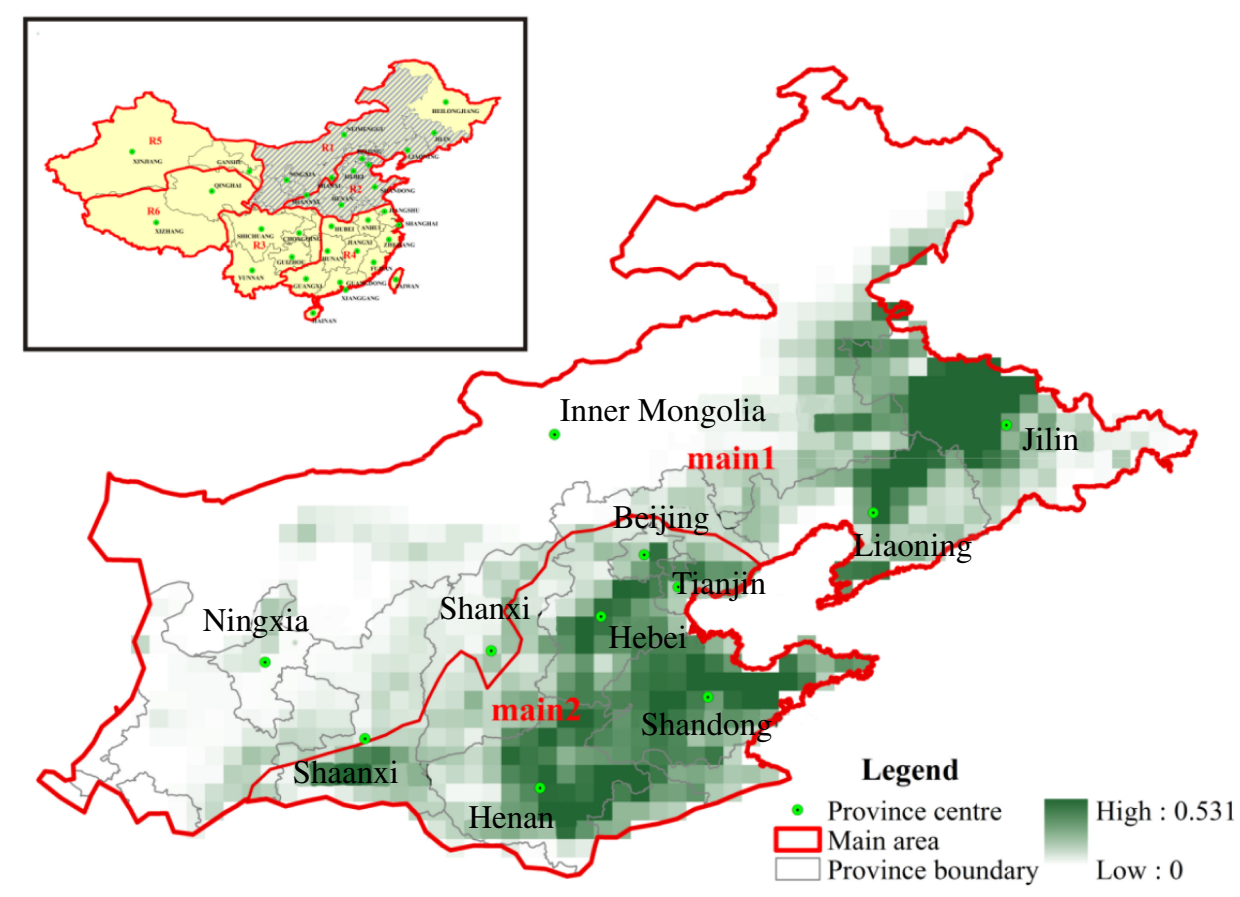

Figure 2. The two main areas (the main1 and main2 areas). As Figure 1, the cultivation fractions are originally from Qiu et al. (2003).

rate and stresses from water. MCWLA adopts a robust, process-based representation of coupled $\mathrm{CO}_{2}$ and $\mathrm{H}_{2} \mathrm{O}$ exchanges. Impacts on yield from factors other than weather (e.g. pests, disease, and management) are modelled in a simplified way. Biomass is calculated cumulatively from the simulated daily photosyntheses values and converted to crop yield by a harvest index. In Tao et al. (2009a), crop yield hindcasts by MCWLA effectively captured interannual variability of crop yield in all four investigated provinces from 1985 to 2002. The impact of extreme temperature on a crop is measured by inhibited and function-limiting photosynthesis at low and high temperatures. Water stress on yield is simulated through soil-moisture stress on daily leaf area index (LAI) development and transpiration, and subsequently on root development, photosynthesis, and canopy conductance (Tao et al., 2009a).

\subsection{Data}

MCWLA-Maize requires at least four meteorological variables: daily mean temperature $T$, daily mean vapour pressure $V_{\text {pr }}$, daily mean solar radiation $S$, and daily total 
precipitation $P$. Monthly data for $T, V_{\mathrm{pr}}, S, P$ and wet days $\left(W_{\text {et }}\right)$ were obtained from the China Meteorological Data Sharing Service System (http://cdc.cma.gov.cn/). Monthly means of temperature, vapour pressure, and solar radiation were interpolated to daily values using spline interpolation (Press et al., 1992). Monthly precipitation was interpolated to daily values using a weather generator, with monthly total precipitation and wet days as inputs, after Gerten et al. (2004). Studies have shown that simulations using interpolated and observed daily data are nearly identical (Tao et al., 2009a, 2009b). T, $V_{\mathrm{pr}}, P$, and $W_{\text {et }}$ were obtained from 755 weather stations all over China for the period 1963-2008. Because only 122 of these stations had $S$ records, $S$ was calculated from sunshine duration (Yang et al., 2001; Yang et al., 2006), which was available at all 755 stations. The MCWLA-Maize model was run on a $0.5^{\circ} \times 0.5^{\circ}$ grid with maize cultivation fraction (ratio between maize cultivation area and total area at a grid) $\geq 0.0$ across the study area (Figure 1). There were a total of 1879 grids in China. As inputs to MCWLA-Maize, the 755-station meteorological data were all interpolated to the $0.5^{\circ} \times 0.5^{\circ}$ grid using a nearest-neighbour method. The sowing date for agrometeorological stations (constructed in 1991) during 1991-2008 was also obtained from the China Meteorological Data Sharing Service System, and average dates during this period were interpolated to the grid. Besides the weather data, soil texture and hydrologic property data were obtained from the FAO soil dataset (Zobler, 1986; FAO, 1991) and used as inputs to MCWLA-Maize.

Maize yield data of each province used for model evaluation in China were taken from China Planting Information, from the China Agricultural Statistical Yearbook and China Statistical Yearbook (http://zzys.agri.gov. $\mathrm{cn} /$ nongqing.aspx). Eighteen provinces have continuous maize yield records from 1961 to 2010 . To remove technological influence on the yields, a 5-year running mean was used to obtain yield residuals (the difference between actual yield and running mean), which were used as observed yields in later analyses, following Zhang et al. (2008). For the simulated yields, the spatially weighted averages for each province were calculated. Weights were defined by the spatial distribution of maize area on a $0.5^{\circ}$ grid (Qiu et al., 2003), assuming that the yearly growing area ratio at each grid did not change throughout the period, as in Tao et al. (2008). Both observed and simulated yields were normalized to the mean technology level of 1990-2000.

For the definition of El Niño (La Niña) events, there are some alternative definitions in the literatures such as Cane et al. (1994), Phillips et al. (1998), Hsiang et al. (2011), and Tack and Ubilava (2013). The sea surface temperature anomaly (SSTA) in the eastern equatorial Pacific is always used as a criterion to distinguish warm/cold ENSO phases from a neutral phase (Royce et al., 2011), such as Niño $1+2$, Niño 3, Niño 3.4, and so on. Following Shuai et al. (2013), El Niño (La Niña) events were defined such that if SSTAs in the region $150^{\circ}-90^{\circ} \mathrm{W}$ and $4^{\circ} \mathrm{N}-4^{\circ} \mathrm{S}$ were at least $+0.5^{\circ} \mathrm{C}\left(\leq-0.5^{\circ} \mathrm{C}\right.$ for La Niña $)$
Table 1. Selected model parameters and prior intervals (See Tao et al., 2009a).

\begin{tabular}{lc}
\hline Parameters & Prior interval \\
\hline Phenological parameters & \\
$T_{\mathrm{b}}\left({ }^{\circ} \mathrm{C}\right)$ & $5-15$ \\
$T_{0}\left({ }^{\circ} \mathrm{C}\right)$ & $20-31$ \\
$T_{\mathrm{m}}\left({ }^{\circ} \mathrm{C}\right)$ & $31-36$ \\
$\mathrm{TDD}_{0}$ (degree-days) & $50-200$ \\
$\mathrm{TDD}_{1}$ (degree-days) & $200-800$ \\
$\mathrm{TDD}_{2}$ (degree-days) & $500-1000$ \\
$\mathrm{TDD}_{3}$ (degree-days) & $700-1200$ \\
$\mathrm{TDD}_{4}$ (degree-days) & $1200-1800$ \\
$\mathrm{Light}_{\mathrm{g}}$ water use and yield formation parameters \\
$Y_{\mathrm{gp}}$ & $0.2-1.0$ \\
$\partial \mathrm{H}_{\mathrm{I}}$ & $0.002-0.02$ \\
$\partial \mathrm{t}$ & $0.2-5.0$ \\
$R_{\mathrm{r}: 1}$ & $0.2-0.8$ \\
$S_{\mathrm{cr}}$ & $0.2-0.8$ \\
$S_{\mathrm{le}}$ & $0.033-0.073$ \\
$\alpha$ & $3.0-15.0$ \\
$T_{\mathrm{max}}\left(\mathrm{mm} \mathrm{m}^{-2}\right.$ day $\left.^{-1}\right)$ & $2.0-10.0$ \\
$g_{\mathrm{m}}$ & $0.2-0.6$ \\
$\lambda_{1}$ & $0.2-0.9$ \\
$R_{\mathrm{m} 25}\left(\mathrm{~g} \mathrm{C} \mathrm{m}^{-2}\right.$ day $\left.^{-1}\right)$ & $10.0-100.0$ \\
$m_{\mathrm{t}}\left(\mathrm{g} \mathrm{C} \mathrm{m}^{-2}\right)$ & $0.1-0.5$ \\
$\alpha_{\mathrm{g}}$ & $0.01-0.2$ \\
$W_{0}\left(\mathrm{~g} \mathrm{C} \mathrm{m}^{-2}\right)$ & \\
\hline
\end{tabular}

for at least six consecutive months and if this 6-month period began prior to or including October and included October-December, the year (October-September) was classified as El Niño (La Niña) (see the definition from the Center for Ocean-Atmospheric Prediction Studies: http://coaps.fsu.edu/jma.shtml). According to this classification, the study period from October 1962 through September 2008 included 12 El Niño (1963/1964, 1965/1966, 1969/1970, 1972/1973, 1976/ 1977, 1982/1983, 1986/1987, 1987/1988, 1991/1992, 1997/1998, 2002/2003, and 2006/2007) and 11 La Niña events (1964/1965, 1967/1968, 1970/1971, 1971/1972, 1973/1974, 1974/1975, 1975/1976, 1988/1989, 1998/ 1999, 1999/2000, and 2007/2008).

\subsection{Calibration and validation of MCWLA-Maize model in each region}

There are 21 parameters in MCWLA-Maize that are relatively important to crop phenology, water use, and yield (Tao et al., 2009a). As in Tao et al. (2009a), approximate ranges of these parameters are specified in Table 1 according to prior knowledge of the parameters. Certain sets of coefficients may be representative of a group of varieties with similar characteristics in a particular geographic area. We assumed that one maturity group variety was sown and the same management practice was implemented across all of one maize cultivated sub-region. A province that was almost entirely included in a sub-region and had large maize cultivated areas was selected as a representative province for calibration. Latin hypercube sampling (Stein, 1987) was used to generate 5000 sets of the 21 parameters as initial parameter sets in each sub-region. The 
gridded weather, soil, and provincial yield data from 1963 to 1985 were used for calibration. Validation for the representative province in each sub-region was done using data from 1986 to 2008. Performance of the MCWLA-Maize model was evaluated by the Pearson correlation coefficient $r$ and root mean square error (RMSE) between the simulated and observed yield at provincial scale. Correlations were considered significant at $P<0.10$. In each sub-region, the 10 best sets of parameters were selected, and then an ensemble-mean yield prediction (EnY) in each grid was obtained by averaging the output of model simulations using those 10 sets $(\mathrm{TeY})$.

2.5. Analyses of mechanisms of ENSO-induced climate variability effects on maize yields

To understand mechanisms underlying the ENSO-yield relationship, we analysed spatial changes of variables related to crop growth and yields during the three ENSO phases. These variables include vapour pressure deficit $V_{\mathrm{PD}}$, soil water stress factor $S_{\text {tress }}$, canopy conductance $g_{\mathrm{c}}$, total precipitation $P$, daily mean solar radiation $S$, maximum temperature $T_{\max }$, and minimum temperature $T_{\min }$ during the maize growth period. Uncertainties of these variables were estimated using the 10 best parameters for each sub-region. Because the uncertainties were very small (not shown here), only ensemble mean values of those variables are presented.

First, we examined the influences of ENSO on maize yields (both model outputs and observed yields) and variables related to maize growth $\left(T_{\max }, T_{\min }, P, S, V_{\mathrm{PD}}, g_{\mathrm{c}}\right.$, and $S_{\text {tress }}$ ) during the growing season. Analysis of variance (ANOVA) was used to test the influence of ENSO phases on maize yield and other variables, and the significance $(P<0.10$ or $P<0.05)$ of ENSO effects on those variables and maize yields was identified by an $F$-test.

To understand the impact mechanisms of ENSO-induced climate variability on maize yields, most parts of R1 (main1 area) and R2 (main2 area), both with large maize cultivation fractions, were selected as the two main areas for in-depth analyses (Figure 2).

In addition, three simulation experiments for neutral years in the main areas were conducted to investigate which meteorological variable contributes most to the reduction of maize yields during La Niña years. The three simulations experiments are (1) reduced $T$ by $2{ }^{\circ} \mathrm{C}$ on all days (with all other variables maintained at earlier levels); (2) reduced $P$ by $20 \%$ on all days (affecting only days with precipitation), and (3) increased $S$ by $4 \mathrm{MJm}^{-2} \mathrm{day}^{-1}$ ( $\sim 20 \%$ of average solar radiation in neutral years) on all days.

\section{Results}

3.1. Validation of MCWLA-Maize in major maize production provinces of China

Heilongjiang, Henan, Sichuan, and Guangxi were chosen as representative provinces for model parameter calibration and validation in R1, R2, R3, and R4, respectively, because these provinces all have large maize cultivation areas. In these provinces, for both TeY and the EnY, $r$ between modelled and observed yield series from 1963 to 2008 was significant, and RMSE values were less than $1400 \mathrm{~kg} \mathrm{ha}^{-1}$ (Table 2). MCWLA-Maize simulated well the interannual variability of maize yields in all four provinces. The $r$ between modelled and observed yield series for EnY was $0.449(P<0.01)$ in Heilongjiang Province, $0.376(P<0.05)$ in Henan Province, 0.535 $(P<0.01)$ in Sichuan Province, and $0.438 \quad(P<0.01)$ in Guangxi Province. RMSE was $571 \mathrm{~kg} \mathrm{ha}^{-1}$ in Heilongjiang, $675 \mathrm{~kg} \mathrm{ha}^{-1}$ in Henan, $256 \mathrm{~kg} \mathrm{ha}^{-1}$ in Sichuan, and $388 \mathrm{~kg} \mathrm{ha}^{-1}$ in Guangxi (Table 2).

In all the other 14 provinces, the performance of MCWLA-Maize was also relatively good. In 6 of the 14, correlations between modelled and observed yields from 1963 to 2008 were highly significant $(P<0.01)$. In 4 of the 14 , correlations were significant $(P<0.05)$. RMSEs in 12 of the 14 provinces were less than $1000 \mathrm{~kg} \mathrm{ha}^{-1}$ (Table 2).

Figure 3 shows the spatial distribution of $r$ and RMSE between modelled and observed yields for EnY in each province. Generally, MCWLA-Maize performed well in nearly all provinces. $r$ in North and Northeast China was higher than in South China, and RMSE in Southwest China was slightly lower than in other areas.

3.2. Spatial patterns of maize yield variability in association with ENSO based on model-simulated and observed yields

Spatial patterns of maize yield variability in association with ENSO using the crop model outputs and observed data are presented in Figure 4. Because EnY simulates well the variability in observed yields, only the pattern of ensemble mean yield variability is shown here. Although the spatial scale is different, the spatial pattern of maize yield variability in association with ENSO derived from the crop model is consistent with that based on observed yields. Results based on the crop model-simulated (Figure 4(a)) and observed yields (Figure 4(c)) both show that during El Niño years, most areas of China (especially the north) had a maize yield increase, whereas some regions in the south had a yield decrease. The results also show an obvious yield decrease mainly in northern and northeastern China and a general increase in the south during La Niña years (Figure 4(b) and (d)). The yield reduces at many northern grids during La Niña years at 90\% and 95\% confidence levels (Figure S1(b), Supporting Information).

Because the spatial scale of the crop model output yields is a $0.5^{\circ} \times 0.5^{\circ}$ grid, much smaller than the province scale of the observed yields, using the crop model outputs can capture the spatial variability of maize yield change at small scales, whereas the observed yields cannot. For example, the statistical results using observed yields only show that yields in Henan Province increased during El Niño years. In contrast, the MCWLA-Maize model results show that total yields increased in that province primarily because of the contribution of southern and northern 


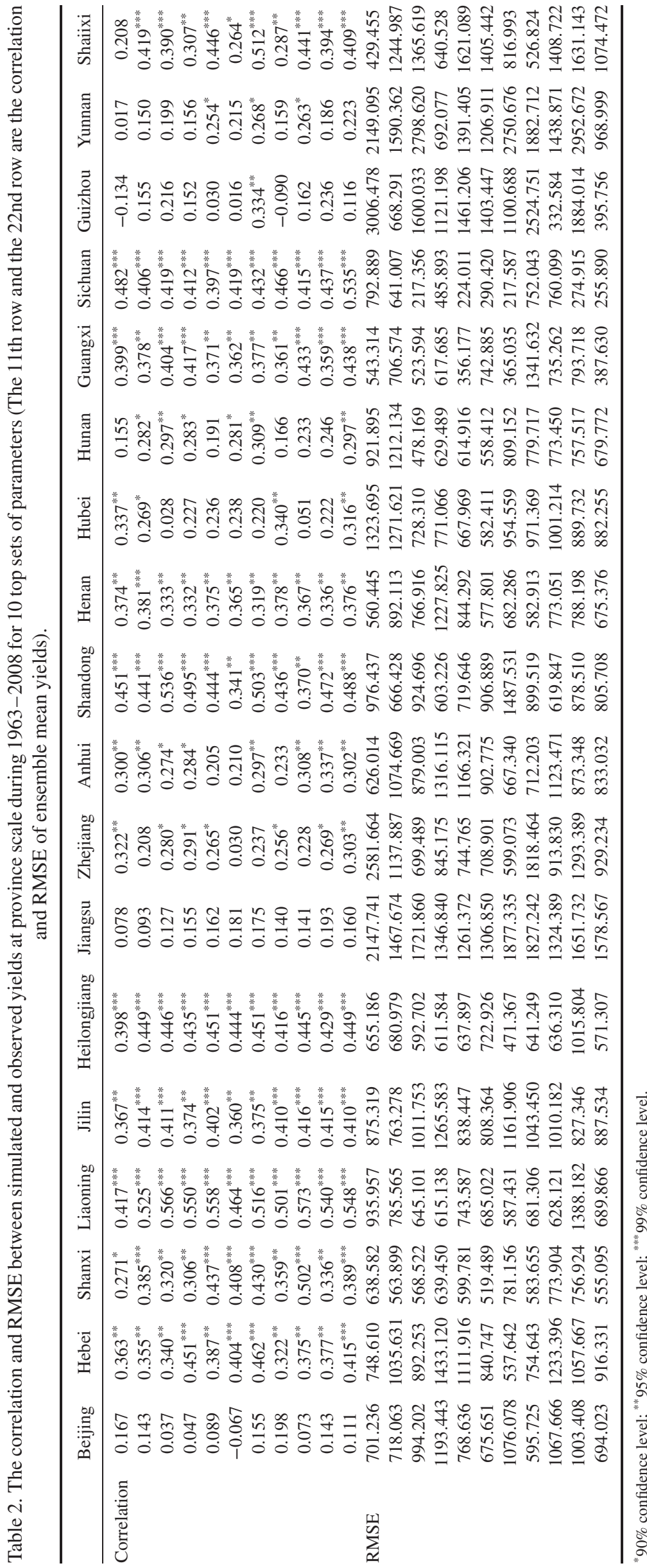



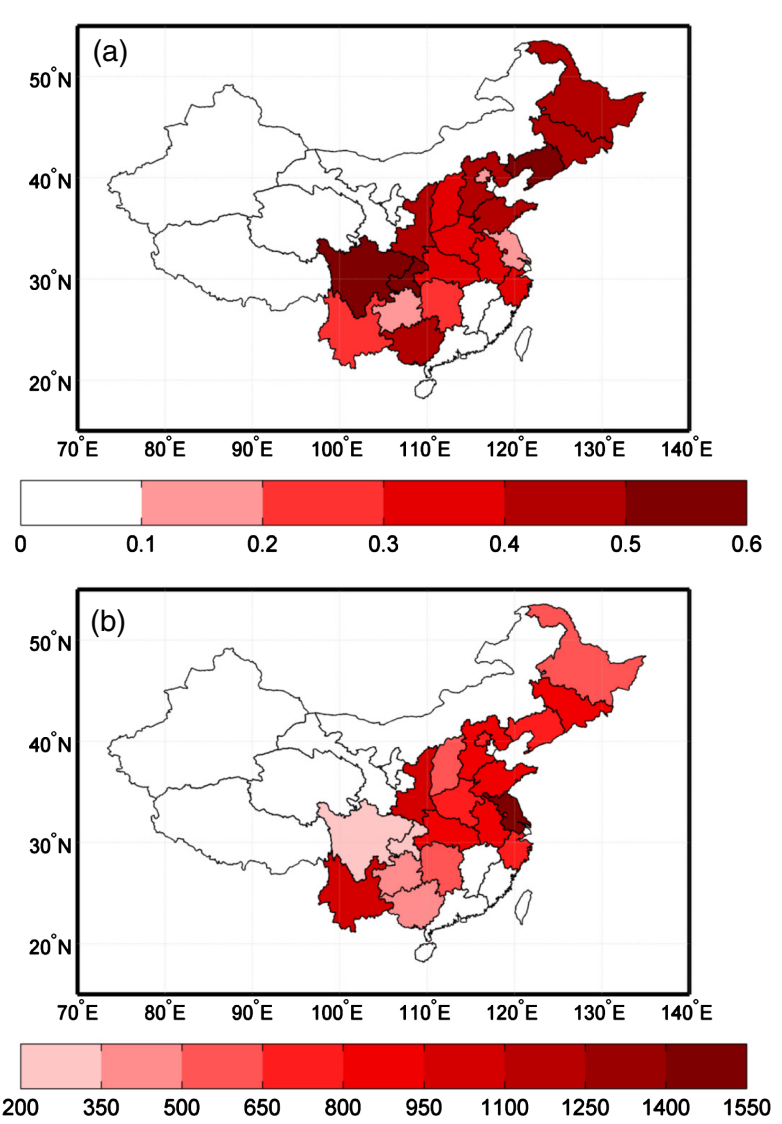

Figure 3. The correlation (a) and the RMSE (b; unit: $\mathrm{kg} \mathrm{ha}^{-1}$ ) between simulated and observed maize yields at province scale during 1963-2008.

portions of the province, but yields declined in the western and eastern portions (Figure 4(a) and (c)). Also, the observed yields cannot be used for some provinces, such as Gansu, because there are no continuous yield records. The crop model, however, may be used to simulate yields using meteorological and environmental data.

\subsection{Variability of climate and soil water conditions in association with ENSO}

According to the results of MCWLA-Maize simulations, the warm phase of ENSO has a positive effect on the amount of $P$. As a result, all China, but especially its central and southeastern areas, average $P$ in El Niño years is greater than that in neutral years (Figure 5(a)). On the contrary, northern China experienced a notably negative effect of La Niña events on $P$, but with some regions in the southwest, east, and northeast showing positive $P$ changes (Figure 5(b)). The decreasing values at many grids in northern China were about $20 \%(15-25 \%)$ of average precipitation during one maize-growing season in neutral years (Figure 5(b)), reaching the 99\% confidence level (Figure S2(b)). For $S$, the spatial distribution of changes affected by ENSO was opposite that for $P$ (Figure 5(c) and (d)). This is because the greater the precipitation, generally the greater the cloudiness and therefore less radiation received at the earth surface. However, the changes of $S$ were generally less than $0.5 \mathrm{MJm}^{-2} \mathrm{day}^{-1}$. In comparison with $P$ and $S$, the impact of ENSO on temperature in China was small. Changes of temperature (both $T_{\max }$ and $T_{\min }$ ) related to ENSO in most regions were no more than $\pm 0.5^{\circ} \mathrm{C}$, although there were weak spatial changes (Figure 5(e)-(h)). $T_{\max }$ decreased during El Niño years and increased in La Niña years on the North China Plain, but there was a decrease of $T_{\max }$ in central China in both warm and cold ENSO phases (Figure 5(e) and (f)). $T_{\text {min }}$ increases were associated with El Niño events in southern China, whereas La Niña events produced reductions of $T_{\text {min }}$ (Figure 5(g) and (h)).

$V_{\mathrm{PD}}$ is a very important variable that affects transpiration, water use, and consequently maize yields (Tao et al., 2009a). $V_{\mathrm{PD}}$ is the difference between saturated $V_{\mathrm{pr}}$ and $V_{\text {pr }}$, and saturated $V_{\mathrm{pr}}$ is calculated from daily mean temperature $T$ (FAO, 1992). Hot and dry days tend to have higher $V_{\mathrm{PD}}$ between the saturated leaf interior and ambient air; in contrast, cool and wet days are often related to lower $V_{\mathrm{PD}}$. The increase of precipitation (Figure 5(a)) and reduction of solar radiation (Figure 5(c)) in most Chinese regions together led to lower $V_{\mathrm{PD}}$ during El Niño years (Figure 5(i)). In La Niña years, corresponding to climate changes (Figure 5(b) and (d)), most areas in the north and northeast and some grids in the south showed higher $V_{\mathrm{PD}}$, reaching the 95 and $99 \%$ confidence levels, respectively (Figure 5(j) and Figure S2(j)). For $g_{c}$, spatial differences between warm and cold ENSO phases were most obvious in northern and northeastern China, with higher values during El Niño years than in neutral years, but lower values during La Niña years (Figure 5(k) and (1)). $S_{\text {tress }}$, defined as the ratio between transpiration and the potential transpiration (Tao et al., 2009a), represents water stress in soil. The lower the $S_{\text {tress }}$, the higher the soil water stress. Figure 5(m) and (n) shows that there was a general increase of $S_{\text {tress }}$ across China during El Niño years, whereas most areas had a reduction of $S_{\text {tress }}$ during La Niña years. Their spatial changes suggest that high $V_{\mathrm{PD}}$ corresponds to low $g_{\mathrm{c}}$ and $S_{\text {tress }}$, and low $V_{\mathrm{PD}}$ on the contrary corresponds to high $g_{\mathrm{c}}$ and $S_{\text {tress }}$.

3.4. Mechanisms of ENSO-induced climate variability impacts on maize yields in two major production areas

\subsubsection{Variability of climate and yield in association with ENSO}

Average temperature, precipitation, and solar radiation during the maize-growing season in the main 1 area were lower than those in main2 (Figure 6(a) and (b)). Because of differences of maize variety and climate between main 1 and main2, average $V_{\mathrm{PD}}, g_{\mathrm{c}}, S_{\text {tress }}$, and yield were also different (Figure 6(a) and (b)). Average $g_{\mathrm{c}}, S_{\text {tress }}$, and yield in main 2 were all higher than those in main 1 , and only $V_{\mathrm{PD}}$ was slightly lower during neutral years.

Regarding the ENSO impacts, they were generally similar between main 1 and main 2 areas. $T_{\max }$ and $T_{\min }$ in both areas during El Niño and La Niña years, except $T_{\max }$ during La Niña years in main1, all showed a slight decrease compared with those during neutral years. In El Niño 

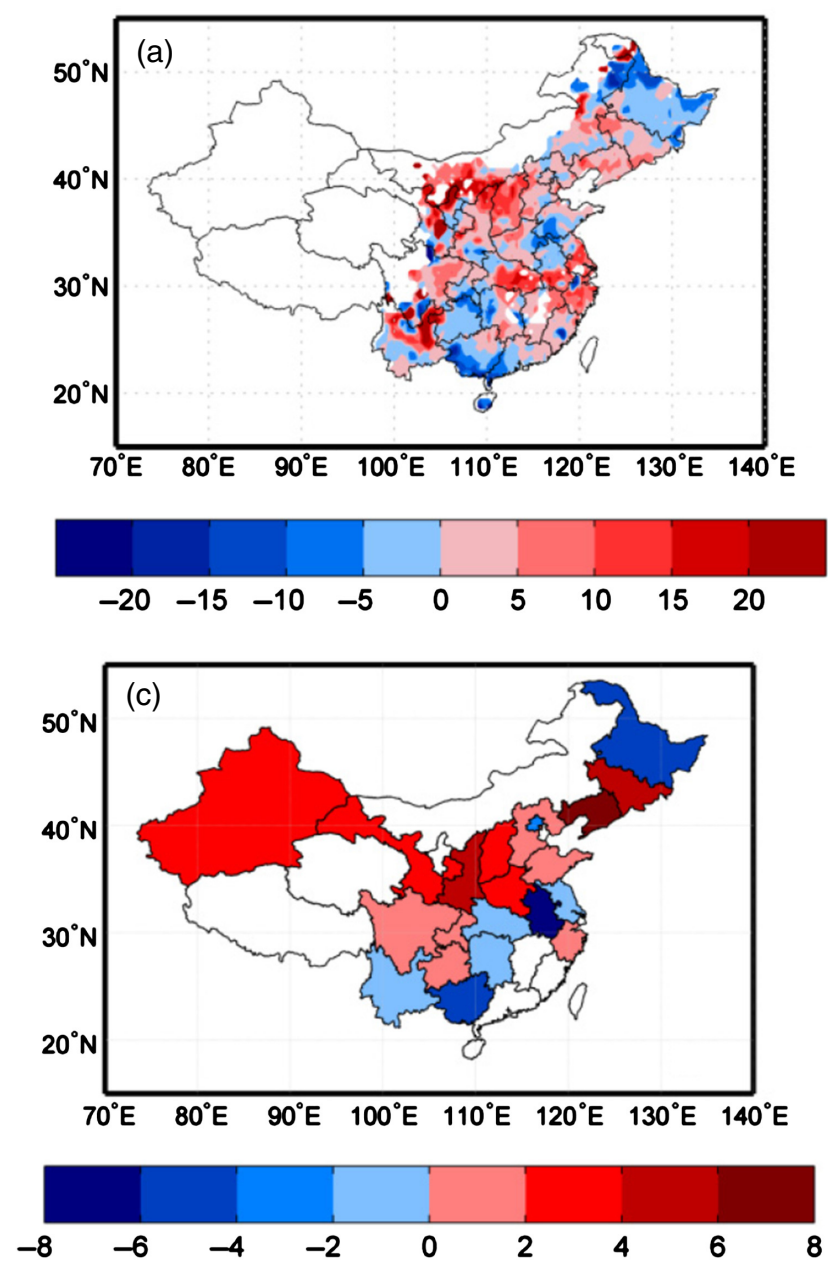
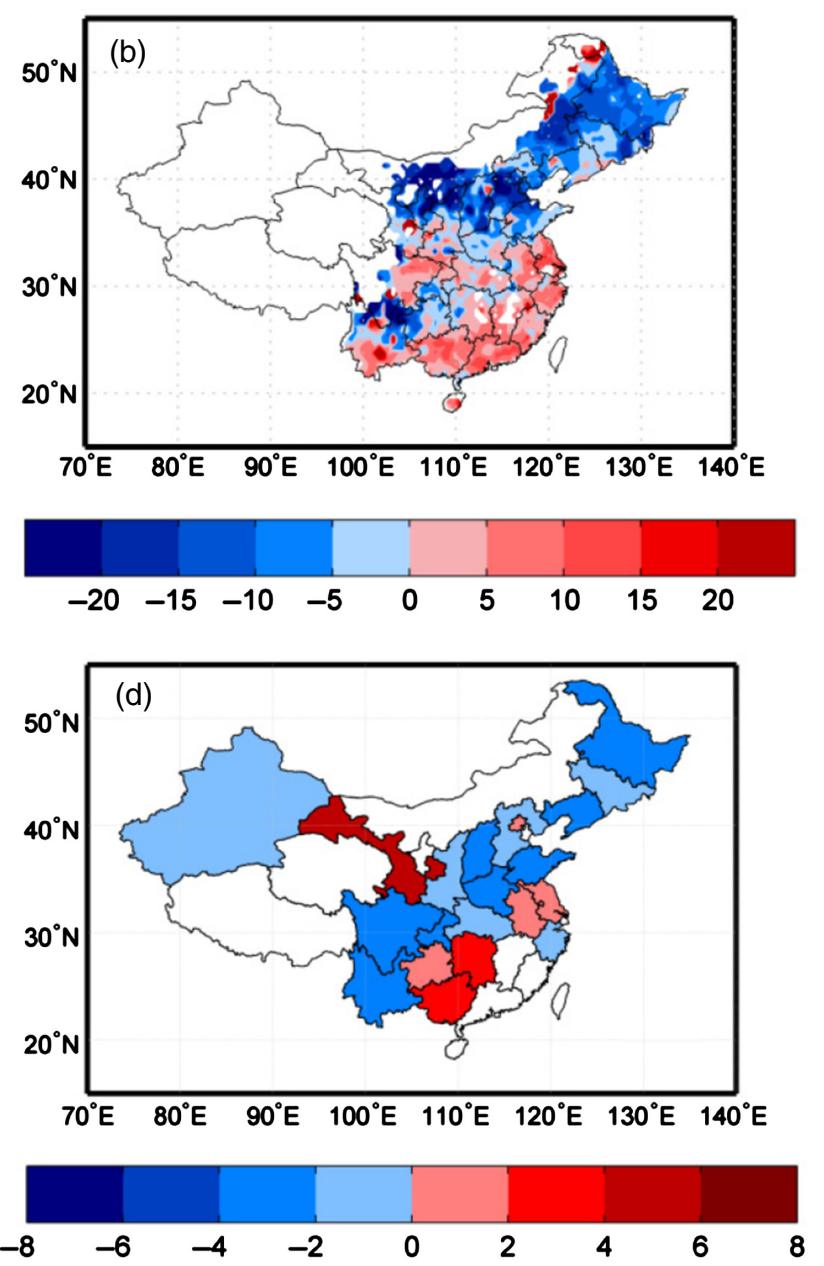

Figure 4. Difference of yield residuals for maize between El Niño years and neutral years (a, c), and between La Niña years and Neutral years (b, d). The yields used for calculating yield residuals in (a) and (b) are the ensemble mean modelled yields simulated by MCWLA; the yields in (c) and (d) are the statistical yields from China Planting Information (http://zzyz.agri.gov.cn/nongqing.aspx). Unit: $100 \%$.

years, $P$ increased from 371 to $390 \mathrm{~mm}$ and 382 to $399 \mathrm{~mm}$, i.e. 5.0 and $4.5 \%$ of average precipitation in the main 1 and main2 areas during neutral years, respectively. Correspondingly, less $V_{\mathrm{PD}}$ and greater $g_{\mathrm{c}}$ and $S_{\text {tress }}$ (and consequently higher yields) were observed. In La Niña years, $P$ and the subsequent $V_{\mathrm{PD}}, g_{\mathrm{c}}, S_{\text {tress }}$, and yield all indicated an opposite change to those in El Niño years. However, $P$ changes during ENSO years in the main1 area were greater than those in main2, especially for $P$ in La Niña years. Also, $S_{\text {tress }}$ and yield in main1 decreased much more than those in main 2 during La Niña years. The changes of $P$ and $S_{\text {tress }}$ were consistent with yield changes in association with ENSO; however, the changes of $V_{\mathrm{PD}}$ and $S$ were opposite to those of yield (Figure 6). Typically, the impacts of La Niña years on yields across the main 1 and main 2 area were stronger than that of El Niño years. The reduction of yields caused by La Niña years was $412.63 \mathrm{~kg} \mathrm{ha}^{-1}$ in main 1 and $310.18 \mathrm{~kg} \mathrm{ha}^{-1}$ in main 2 area, respectively.

\subsubsection{Mechanisms underlying ENSO-induced variability of maize yields}

To evaluate mechanisms underlying ENSO-induced variability of maize yields using MCWLA-Maize, several key variables for maize growth and yield in the main areas are presented. The changes of $P$ and $S_{\text {tress }}$ were consistent with those of yield in association with ENSO. However, the changes of $V_{\mathrm{PD}}$ and $S$ were opposite to those of yield (Figure 6), suggesting water stress as a key mechanism for ENSO-induced variability of maize yields. Figure 7 indicates that simulated $P, T_{\max }, T_{\min }$, and $S$ all had certain relationships with $V_{\mathrm{PD}}$ in the maize growing season, suggesting that those four variables influence yields mainly by modulating $V_{\mathrm{PD}}$ and subsequent water stress. The slope of the $T-V_{\mathrm{PD}}$ relationship is much steeper than those of $P-V_{\mathrm{PD}}$ and $S-V_{\mathrm{PD}}$. A reduction of $T_{\max }$ from $27^{\circ} \mathrm{C}$ to $25^{\circ} \mathrm{C}$ caused $\sim 0.3 \mathrm{kPa}$ decrease of $V_{\mathrm{PD}}$ in the main 1 area, whereas a $P$ increase of $200-300 \mathrm{~mm}$ or an $S$ reduction from $18-16 \mathrm{MJ} \mathrm{m}^{-2}$ day $^{-1}$ produced no more than $0.1 \mathrm{kPa}$ decrease of $V_{\mathrm{PD}}$. Either directly or through influencing $g_{\mathrm{c}}$, $V_{\mathrm{PD}}$ would affect $S_{\text {tress }}$, thereby controlling maize yields (Figure 7(e)-(h)). In the MCWLA-Maize simulation, the relationship between $V_{\mathrm{PD}}$ and $g_{\mathrm{c}}$ is not a simple linear one in which extreme high and low $V_{\mathrm{PD}}$ can both lower $g_{\text {c }}$. Consequently, the relationship between $V_{\mathrm{PD}}$ and $S_{\text {tress }}$ is also complicated. The relationship between $S_{\text {tress }}$ and maize yield is generally a positive one, especially when 

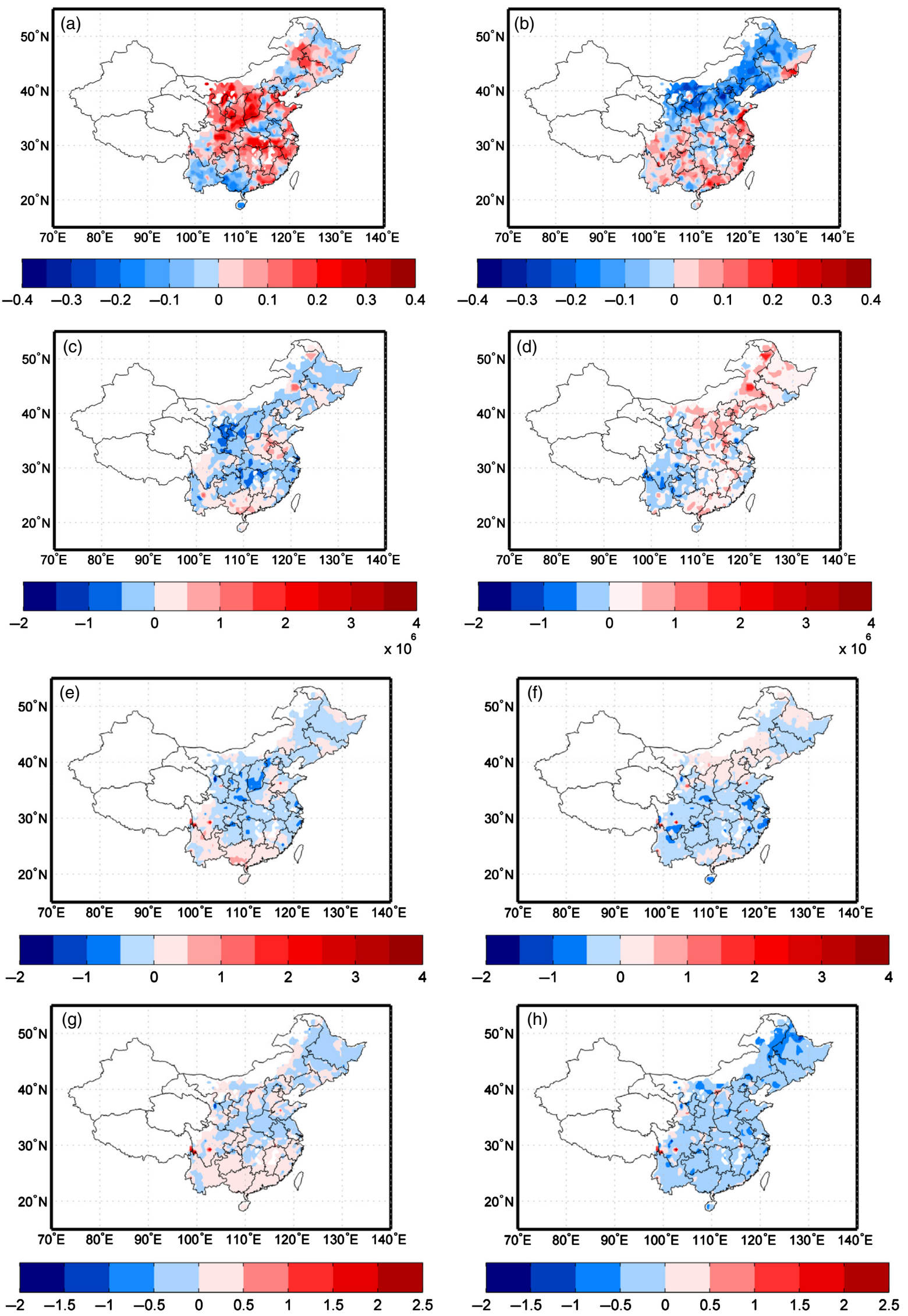

Figure 5. The difference of total precipitation $(P)(\mathrm{a}, \mathrm{b}$; unit: $100 \%)$, daily solar radiation $(S)\left(\mathrm{c}, \mathrm{d}\right.$; unit: $\mathrm{J} \mathrm{m}^{-2}$ day $\left.^{-1}\right)$, daily maximum temperature $\left(T_{\max }\right)\left(\mathrm{e}, \mathrm{f} ;\right.$ unit: $\left.{ }^{\circ} \mathrm{C}\right)$, daily minimum temperature $\left(T_{\min }\right)\left(\mathrm{g}, \mathrm{h}\right.$; unit: $\left.{ }^{\circ} \mathrm{C}\right)$, vapour pressure $\left(V_{\mathrm{PD}}\right)(\mathrm{i}, \mathrm{j}$; unit: $\mathrm{kPa})$, canopy conductance $\left(g_{\mathrm{c}}\right)(\mathrm{k}, 1 ;$ unit: $\left.\mathrm{mm} \mathrm{m}^{2} \mathrm{day}^{-1}\right)$, and soil water stress factor $\left(S_{\text {tress }}\right)(\mathrm{m}, \mathrm{n})$ during maize growing season between El Niño years and neutral years (left column) and between La Niña years and neutral years (right column). All these results are calculated from ensemble runs. 

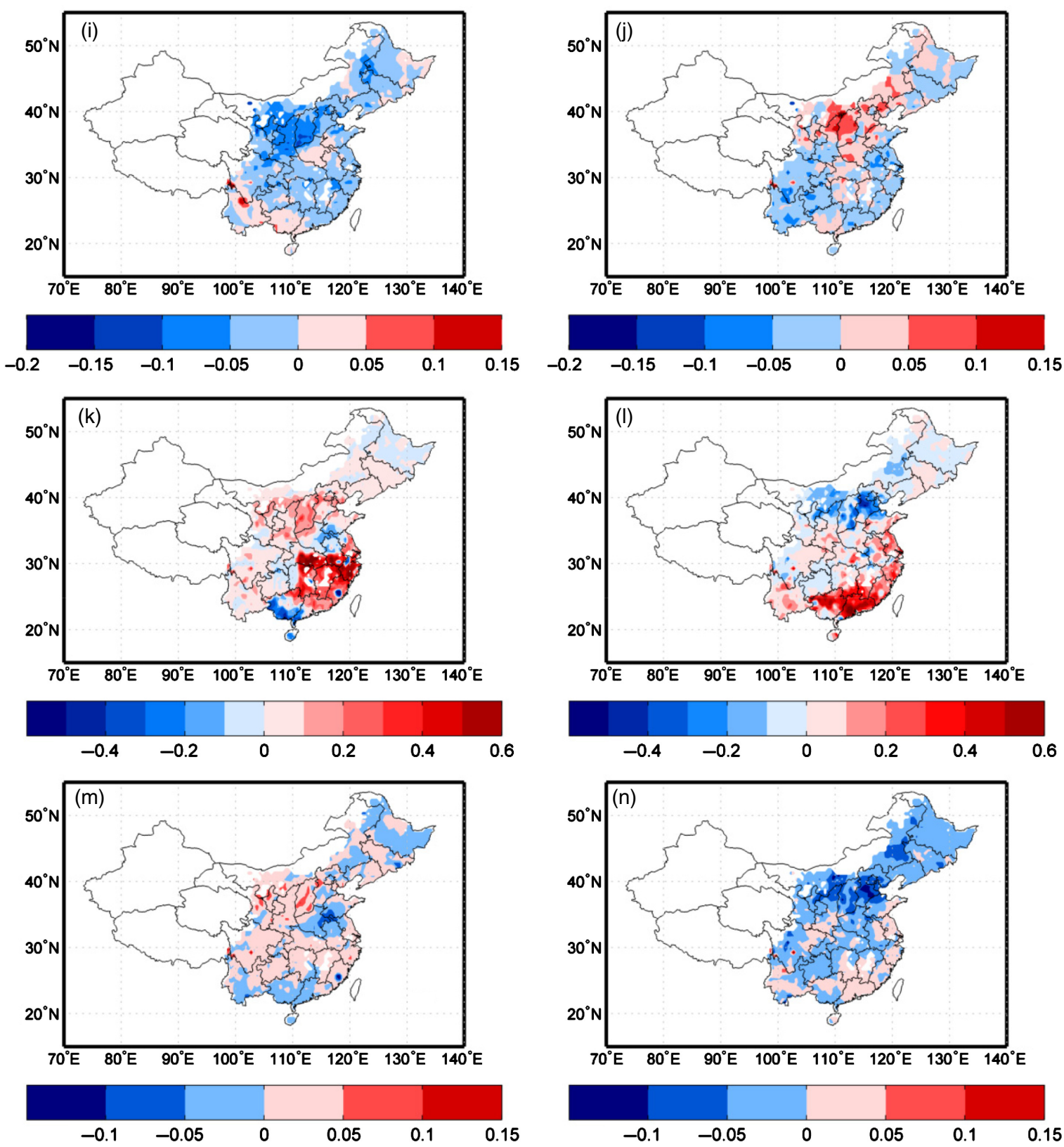

Figure 5. Continued.

$S_{\text {tress }}$ is low. However, such a positive relationship becomes weak or even slightly negative when $S_{\text {tress }}$ exceeds 0.8 (Figure 7(h)). Therefore, the mechanism of meteorological variable impacts on maize yield is complex. However, $V_{\mathrm{PD}}$ is a key factor linking climate and final maize yields. Extreme high or low $V_{\text {PD }}$ may both limit yield.

According to the above analysis, the reduction of maize yield in La Niña years is the result of changes to $V_{\mathrm{PD}}$ and water stress, which are affected by temperature, precipitation, and solar radiation. However, which meteorological variable contributes most to the yield reduction remains unclear. To answer this question, three modelling experiments using MCWLA-Maize were performed. Surprisingly, yields were most sensitive to changes of $T$ rather than $P$ and $S$ (Figure 8). With a $2{ }^{\circ} \mathrm{C} T$ decrease, yields declined dramatically by $\sim 30 \%$, especially in the main1 area. $V_{\mathrm{PD}}$ dropped significantly in both main areas, with values less than 0.5 . Consequently, $g_{c}$ and $S_{\text {tress }}$ in the maize-growing season both declined, with average reductions $\sim 0.2$ and $\sim 0.12 \mathrm{~mm} \mathrm{~m}^{2}$ day $^{-1}$, respectively, in the main1 area, and $\sim 0.05$ and $\sim 0.08 \mathrm{~mm} \mathrm{~m}^{2}$ day $^{-1}$ in main2. With $P$ reduced by $20 \%$, the response of $V_{\mathrm{PD}}$ was weak, and the decreases of $g_{\mathrm{c}}$ and $S_{\text {tress }}$ had less impact than the $2{ }^{\circ} \mathrm{C}$ decrease of $T$. Except for $g_{\mathrm{c}}$ in main2, $S_{\text {tress }}$ in both areas, and $g_{\mathrm{c}}$ in main1, all had more significant responses to $T$ than $P$. Thus, because of the strong responses of $V_{\mathrm{PD}}$, $g_{\mathrm{c}}$, and $S_{\text {tress }}$ to $T, P$ had relatively little control on maize yield.

The impact of ENSO on $P$ was much more significant than that on $T$ in northern and northeastern China. In the two main areas (Figure 2), the changes of $T$ (both $T_{\max }$ and $T_{\text {min }}$ ) were no more than $0.25^{\circ} \mathrm{C}$ during ENSO 

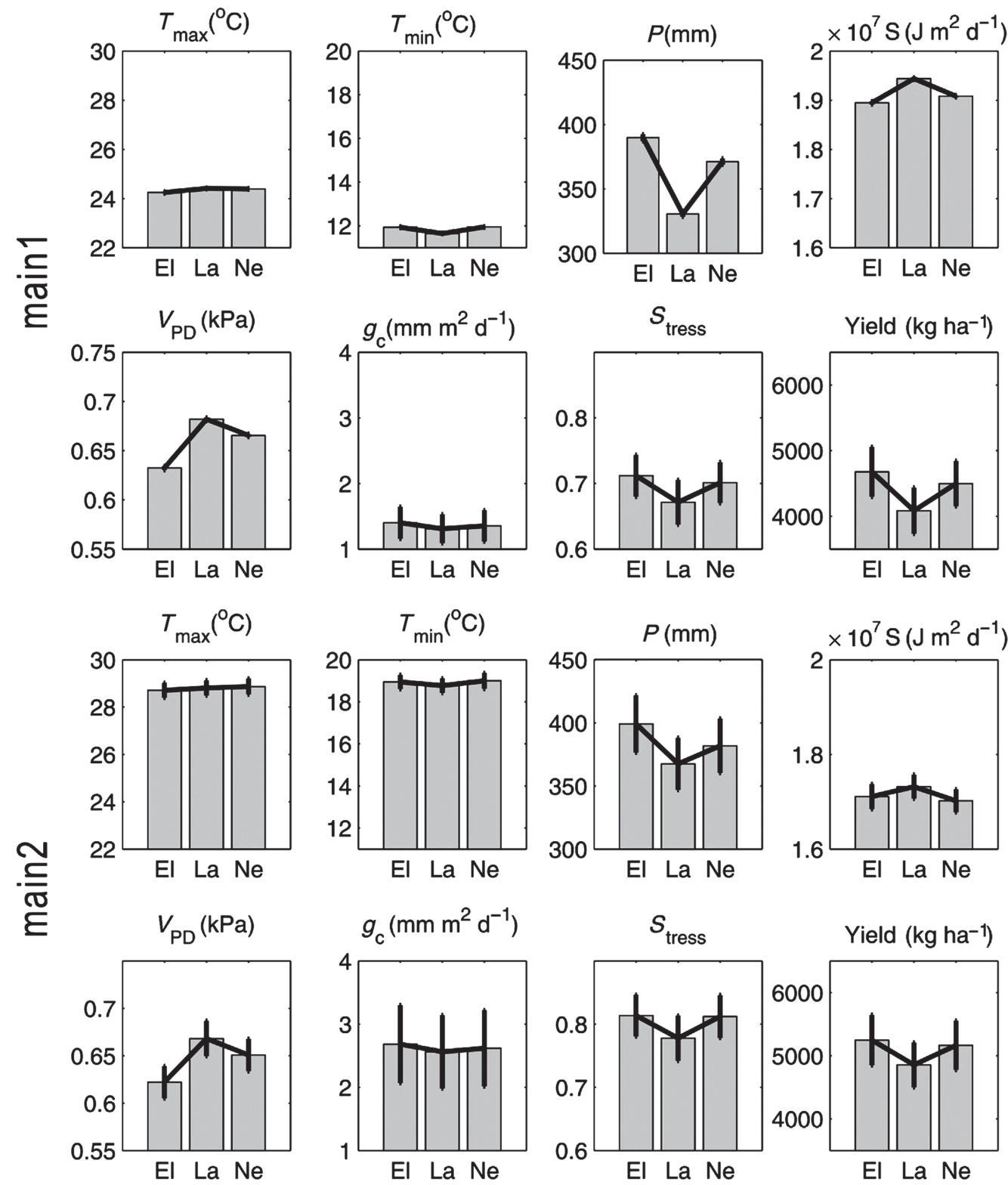

Figure 6. Bar plot of daily maximum temperature $\left(T_{\max }\right)$, daily minimum temperature $\left(T_{\min }\right)$, solar radiation $(S)$, vapour pressure $\left(V_{\mathrm{PD}}\right)$, canopy conductance $\left(g_{\mathrm{c}}\right)$, soil water stress factor $\left(S_{\text {tress }}\right)$, and total precipitation $(P)$ during maize growing season, and yield in the main1 area (a) and main2 area (b) among different ENSO phases. The black lines on each bar show the standard deviation of the simulation.

years, whereas average $P$ decreased $\sim 41 \mathrm{~mm}$ (about 11\%) in the main 1 area and $\sim 15 \mathrm{~mm}(\sim 4 \%)$ in main2 during La Niña years. As a result, although maize yields were very sensitive to $T$ changes, the strong $P$ changes during ENSO years had greater impacts on yields in northern and northeastern China. As for the impacts of increased $S$, the variables $V_{\mathrm{PD}}, g_{\mathrm{c}}$, and $S_{\text {tress }}$ all showed few changes relative to the original data, resulting in few yield changes in the simulation results of MCWLA-Maize. Thus, more attention should be paid to the variability of $P$ during ENSO years.

It was also found that the effects of decreasing $P$ on maize were much stronger in the main 1 area than in main2. A $20 \% P$ reduction led to decreases of $\sim 8.5 \%$ in $g_{c}$ and $\sim 6.0 \%$ in $S_{\text {tress }}$ in main1, but only $\sim 4.0 \%$ and $\sim 3.4 \%$ corresponding reductions in main2. As a result, yields in main 1 were reduced by $\sim 11.8 \%$, nearly twice that $(\sim 5.0 \%)$ in main2. This further indicates that $P$ changes had greater effects in drier areas than those in wetter areas, such as main1 versus main2.

\section{Discussion}

4.1. Consistent patterns of variability in climate and soil water conditions in association with ENSO

Spatial patterns of variability in climate and soil water conditions in association with ENSO based on model simulations are consistent with previous studies on the effect of ENSO on precipitation in China (e.g. Huang and Wu, 1989; Zhu et al., 2007). With SSTA rise in the eastern tropical Pacific, the subtropical high over East Asia is 
(a)

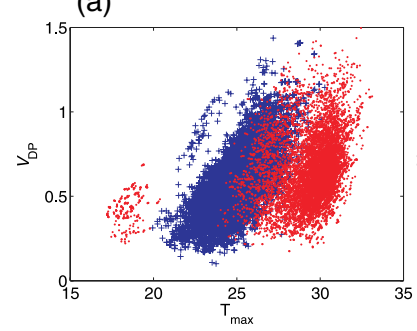

(e)

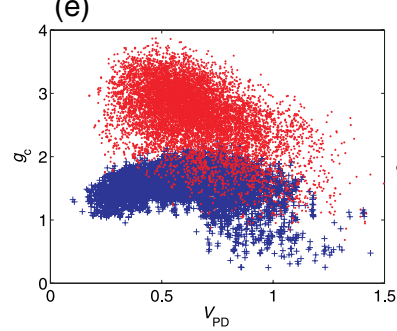

(b)
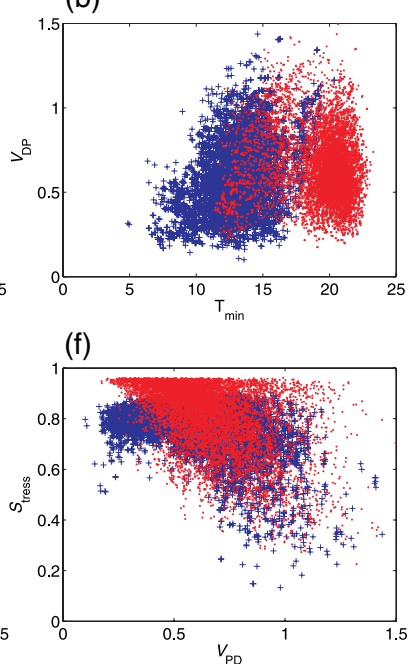

(c)

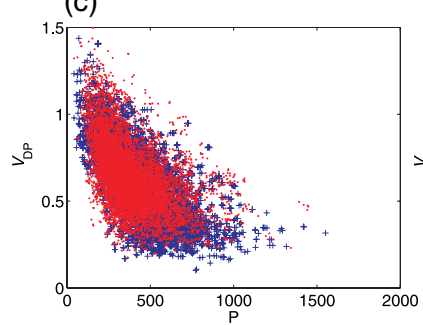

(g)

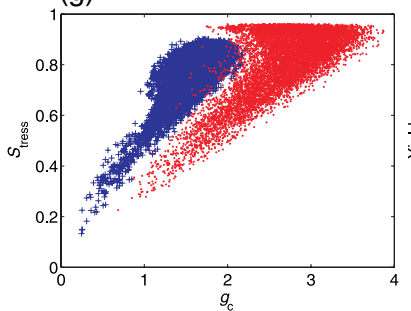

(d)

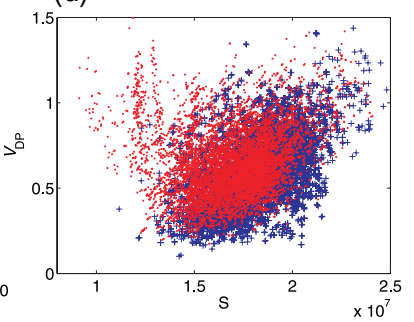

(h)

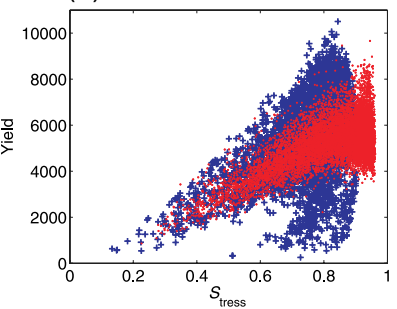

Figure 7. Scatter plots between variables shown in Figure 6. In each figure, the blue crosses represent the main 1 area while the red dots represent the main2 area. [(a) $V_{\mathrm{PD}}$ (unit: $\mathrm{kPa}$ ) versus $T_{\max }$ (unit: ${ }^{\circ} \mathrm{C}$ ); (b) $V_{\mathrm{PD}}$ (unit: $\mathrm{kPa}$ ) versus $T_{\min }$ (unit: ${ }^{\circ} \mathrm{C}$ ); (c) $V_{\mathrm{PD}}$ (unit: $\left.\mathrm{kPa}\right)$ versus $P$ (unit: $\mathrm{mm}$ ); (d) $V_{\mathrm{PD}}$ (unit: $\mathrm{kPa}$ ) versus $S\left(\mathrm{~J} \mathrm{~m}-^{2} \mathrm{day}^{-1}\right)$; (e) $g_{\mathrm{c}}$ (unit: $\mathrm{mm} \mathrm{m}^{2}$ day $^{-1}$ ) versus $V_{\mathrm{PD}}$ (unit: $\left.\mathrm{kPa}\right)$; (f) $S_{\text {tress }}$ versus $V_{\mathrm{PD}}$ (unit: $\mathrm{kPa}$ ); (g) $S_{\text {tress }}$ versus $g_{\mathrm{c}}$ (unit: $\mathrm{mm}$ $\left.\mathrm{m}^{2} \mathrm{day}^{-1}\right)$; (h) yield $\left(\mathrm{kg} \mathrm{ha}^{-1}\right)$ versus $\left.S_{\text {tress }}\right]$.
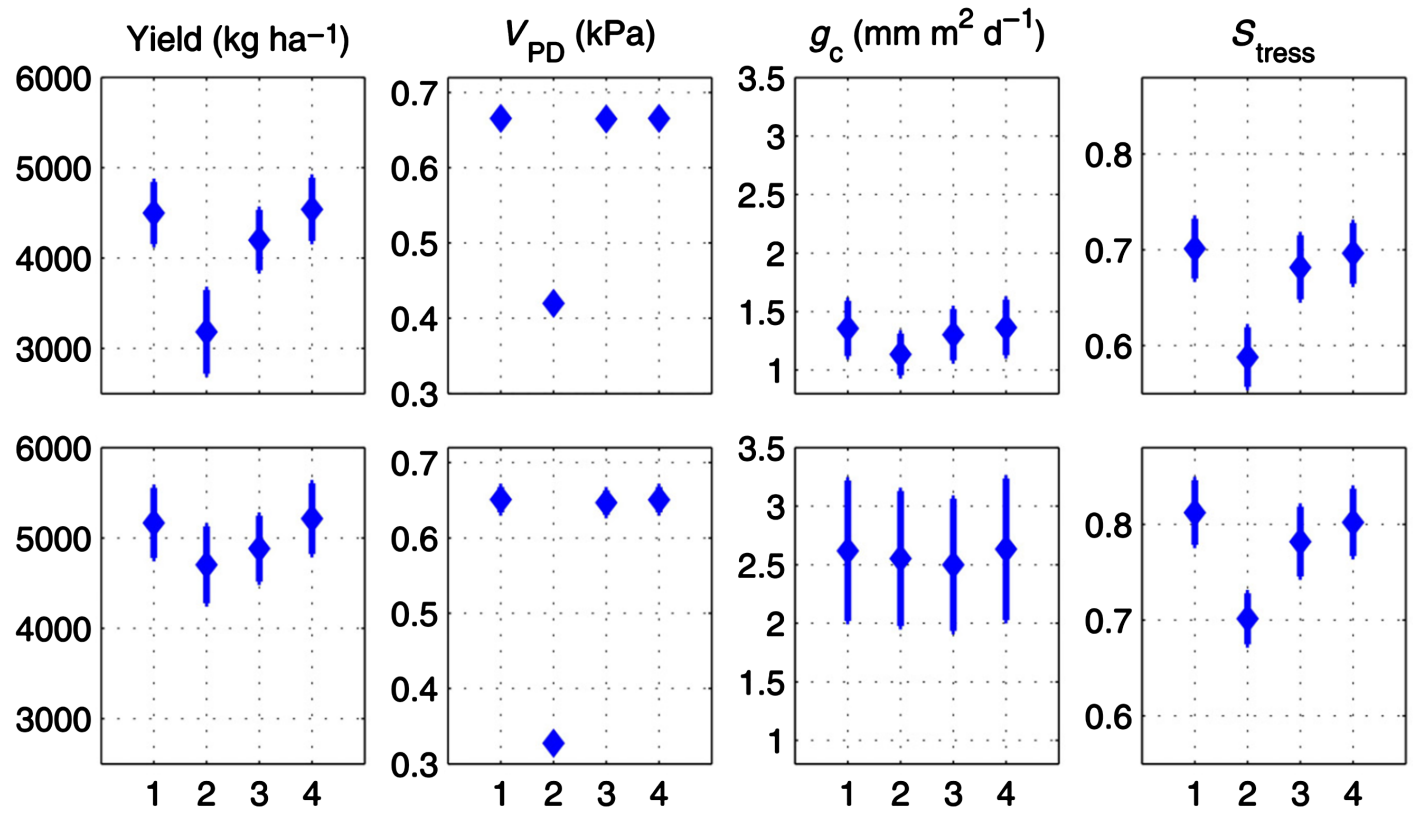

Figure 8. Plot of daily mean $V_{\mathrm{PD}}, g_{\mathrm{c}}, S_{\text {tress }}$, and yield during maize growing season in neutral years with different scenarios (1: original, 2: reduce $2{ }^{\circ} \mathrm{C}$ per day; 3: reduce $20 \%$ precipitation per day; 4: increase 4E6 J radiation per day). The up row is for the main 1 area, and the bottom row is for the main 2 area. The lines on each point show the standard deviation of the simulation.

much stronger, and there is a corresponding anticyclonic anomaly in the low-level wind field under the subtropical high. Air with more moisture over low-latitude seas is thereby transported to China by southeasterly winds to the southwest of the anticyclonic anomaly; the situation is reversed for La Niña events (Wu et al., 2003; Feng and $\mathrm{Li}, 2011)$. The resultant impact of ENSO on temperature in China is small, but consistent with Liu and Ding (1995). The spatial patterns of all meteorological variable changes are also generally consistent with the statistical results of Shuai et al. (2013). There are slight inconsistencies, however, which may result from differences of spatial scale and growing season dates between the present study and Shuai et al. (2013). In the latter study, the spatial scale was that of the province and the growing season was defined by approximate months. In our model simulation, the grid was the spatial scale and average sowing dates for each agrometeorological station were used to derive the growing season at each grid.

The spatial changes in $V_{\mathrm{PD}}, g_{\mathrm{c}}$, and $S_{\text {tress }}$ suggest that high $V_{\mathrm{PD}}$ corresponds with low $g_{\mathrm{c}}$ and $S_{\text {tress }}$, and low $V_{\mathrm{PD}}$ in contrast corresponds with high $g_{\mathrm{c}}$ and $S_{\text {tress }}$. Such phenomena are consistent with crop growth mechanisms in which plants typically respond to high $V_{\mathrm{PD}}$ by reducing stomatal 
conductance $\left(g_{c}\right)$, which effectively retains soil moisture for periods with less evaporative demand (Sinclair et al., 1984 ) and meanwhile reduces $S_{\text {tress }}$ (Ray et al., 2002; Hetherington and Woodward, 2003; Liu et al., 2004; Ribaut et al., 2009).

\subsection{ENSO effect on yield variability via its primary influence on water stress}

We found that changes of $P$ and $S_{\text {tress }}$ are consistent with yield variations in association with ENSO. However, changes to $V_{\mathrm{PD}}$ and $S$ are opposite to those of yield, suggesting water stress as the key mechanism of ENSO-induced variability of maize yields. In-depth analyses show that the ENSO-induced meteorological impacts on yields, not only those of $P$ but also of $T$ and $S$, all proceed by influencing soil water conditions (i.e. $V_{\mathrm{PD}}, g_{\mathrm{c}}$, and $\left.S_{\text {tress }}\right)$. Modelling experiments suggest that the responses of $V_{\mathrm{PD}}, g_{\mathrm{c}}$, and $S_{\text {tress }}$ to a $2^{\circ} \mathrm{C}$ decrease of $T$ are much stronger than a $20 \%$ decrease of $P$, indicating that change of $T$ should have great impacts on $V_{\mathrm{PD}}, g_{\mathrm{c}}, S_{\text {tress }}$, and consequently yield. The findings are consistent with the model simulations of Lobell et al. (2013), which revealed that large $P$ changes are required to rival the effect of $T$ on water stress and maize yield. Effects of $S$ on $V_{\mathrm{PD}}$, water stress, and yield are complex. An increase of $S$ can increase photosynthesis and transpiration, which can benefit crop yield, especially in well-fertilized and irrigated fields (Fischer, 1985). However, an $S$ increase can also augment evapotranspiration and consequently aggravate water stress and reduce yield (Tao et al., 2003). We found that $S$ increases at high $S$ levels boost $V_{\mathrm{PD}}$ in dry areas, but had little effect on $V_{\mathrm{PD}}$ in wet areas with low $S$ levels in the main 1 and main2 areas (Figure 7(d)). Given these contrasting roles and diverse environments, slight increases of $S$ in La Niña years slightly increased $V_{\mathrm{PD}}$, water stress, and yield in main1 and main2.

Soil water balance is an important intermediary variable that converts climatic variability to yield variability. Because soil water conditions are important in controlling land surface-atmosphere interaction through processes such as evapotranspiration, latent heat and sensible heat fluxes, and atmospheric boundary layer dynamics, they are a part of ENSO-related hydroclimatic anomalies (Wu and Kinter, 2009; Poveda et al., 2011). Further, crop yields are closely related to amounts of available soil water that can be taken up by plant roots during crop growth and development seasons (Nielsen et al., 2009; Grassini et al., 2011). Thus, soil water conditions serve as a bridge between ENSO-induced climate change and maize yield.

This linking role of soil water gives insight into adaptations to ENSO-related climate changes. In practice, we cannot reduce yield losses from disastrous climate effects such as those during La Niña years in the main areas, but it is feasible to use certain measurements to alter soil water conditions and increase potential yields. In our case, the reduction of maize yields in La Niña years is mainly caused by lack of soil water caused by changes of $T, S$, and especially $P$. Thus, properly increasing irrigation water in the main areas may be useful.

Northern and northeastern China are relatively water-short parts of the country, and limited precipitation always restricts crop yield there (Mo et al., 2005; Lin et al., 2013). Many studies have suggested that there is potential to increase yields in this region if sufficient irrigation water is supplied (Zhang et al., 1999; Mo et al., 2005; Sun et al., 2006). Although efficient use of irrigation water and advancements of production efficiency in China have improved over recent decades ( $\mathrm{Li}$ and Barker, 2004; Shahbaz et al., 2006), water shortages in the dry regions remain severe, with typical agricultural water use efficiency about $0.46 \mathrm{~kg} \mathrm{~m}^{-3}$ (Deng et al., 2006). Thus, to cope with the disadvantageous climate in La Niña years, it is advisable to improve irrigation systems in the main areas, especially the dry portions, to ensure adequate irrigation water for agriculture.

\subsection{Uncertainties of the study}

The parameters in our study were calibrated in one province in each sub-region, and the ensemble predictions can account for physical and biological uncertainty (Challinor et al., 2005). Similar to other works (e.g. Tao et al., 2009a, 2009b; Tao and Zhang, 2010), the biophysical uncertainties in the MCWLA-Maize impact assessments are considered using 10 sets of optimal crop model parameters. The reductions of maize yield during La Niña years ranged from 3736 to $4437 \mathrm{~kg} \mathrm{ha}^{-1}$ and 4504 to $5208 \mathrm{~kg} \mathrm{ha}^{-1}$ in the main 1 and main 2 areas, respectively. Although uncertainty in phenological parameters of crop cultivars is considered to some extent, the parameters were calibrated based on average conditions during 1963-2008. Maize cultivars were assumed invariant over those 46 years. Furthermore, uncertainties from meteorological variables, such as those of responses of precipitation to ENSO, were not examined herein. The data analysis, including yield detrending, interpolation of the meteorological data, and others, might have also introduced uncertainties in the present results. Although the crop model has good simulation performance in most areas, a relatively low $r$ in certain areas (such as in southwestern China) may hinder accuracy in assessing the impacts of climate variability on maize yield. Finally, although the spatially heterogeneous effects of ENSO we presented here are fairly reasonable, further tests of the spatial differences are still necessary.

\section{Conclusion}

Using the process-based model MCWLA-Maize, we simulated the growth and development of maize to understand how ENSO impacts its yield in China at $0.5^{\circ} \times 0.5^{\circ}$ grid scale. The simulations were consistent with our previous statistical study (Shuai et al., 2013) and furnished additional insights regarding the ENSO-yield relationship in the country. 
From the national spatial simulations, temperature had little connection with the ENSO-yield relationship, but $P$ and $S$ had significant contributions to that relationship. Specifically, increases (decreases) of $P$ and reductions (increases) of $S$ in the decaying phase of El Niño (La Niña) years generated decreases (increases) of $V_{\mathrm{PD}}$, increases (decreases) of $g_{c}$ and $S_{\text {tress }}$, and ultimately increases (decreases) of yields in northern and northeastern China. In-depth analyses of two main areas (i.e. northern and northeastern China) suggest that relationships between temperature and yield are very complex and that a $2{ }^{\circ} \mathrm{C}$ change of temperature exerts more control on yields than a $20 \%$ change of $P$ or $4 \mathrm{MJm}^{-2}$ day $^{-1}$ change of $S$. However, the effect of ENSO on $P$ on most grids in northern and northeastern China was about $20 \%$, whereas variations of $T$ and $S$ were relatively small. This demonstrates that $P$ is the main influence on the ENSO-yield relationship. A comparison between two sub-main areas indicated that maize yields in dry regions are much more sensitive to meteorological variable changes than those in wet regions. Thus, it is advisable to pay more attention to $P$ changes during ENSO years in relatively dry areas.

Finally, based on the above analysis, we recommend development of a food security warning system that predicts potential yield variations based on ENSO forecast information. To understand accurately the impacts of ENSO on crop yield, meteorological uncertainties should be considered as an integral part of that system. Therefore, more integrated assessments that consider ENSO and agricultural systems as a whole should be conducted to provide effective agricultural information to government decision makers and farmers.

\section{Acknowledgements}

This study was supported by the National Basic Research Program of China (2012CB955404), the Fund for Creative Research Groups of National Natural Science Foundation of China (No. 41321001), the National Science Foundation of China (No. 41071030), the strategic pilot scientific projects of the Chinese Academy of Science (Project Number XDA05090308), and the National Key Programme for Developing Basic Science (Project Number 2010CB950902).

\section{Supporting Information}

The following supporting information is available as part of the online article:

Figure S1. The significance of ANOVA test of yield residuals for maize between El Niño years and Neutral years (a), and between La Niña years and neutral years (b). Only the grids with $p<0.1$ are filled with colour.

Figure S2. The significance of ANOVA test of total precipitation $(P)(\mathrm{a}, \mathrm{b})$, daily solar radiation $(S)(\mathrm{c}, \mathrm{d})$, daily maximum temperature $\left(T_{\max }\right)(\mathrm{e}, \mathrm{f})$, daily minimum temperature $\left(T_{\min }\right)(\mathrm{g}, \mathrm{h})$, vapour pressure $\left(V_{\mathrm{PD}}\right)(\mathrm{i}, \mathrm{j})$, canopy conductance $\left(g_{\mathrm{c}}\right)(\mathrm{k}, \mathrm{l})$, and soil water stress factor $\left(S_{\text {tress }}\right)$ $(\mathrm{m}, \mathrm{n})$ during maize growing season between El Niño years and neutral years (left column) and between La Niña years and neutral years (right column). Only the grids with $p<0.1$ are filled with colour.

\section{References}

Alexander LV, Uotila P, Nicholls N. 2009. Influence of sea surface temperature variability on global temperature and precipitation extremes. J. Geophys. Res. 114: D18.

Almaraz JJ, Mabood F, Zhou X, Gregorich EG, Smith DL. 2008. Climate change, weather variability and corn yield at a higher latitude locale: Southwestern Quebec. Clim. Change 88(2): 187-197.

Bassu S, Brisson N, Durand J-L, Boote K, Lizaso J, Jones JW, Rosenzweig C, Ruane AC, Adam M, Baron C, Basso B, Biernath C, Boogaard H, Conijn S, Corbeels M, Deryng D, De Sanctis G, Gayler S, Grassini P, Hatfield J, Hoek S, Izaurralde C, Jongschaap R, Kemanian AR, Kersebaum KC, Kim S-H, Kumar NS, Makowski D, Müller C, Nendel C, Priesack E, Pravia MV, Sau F, Shcherbak I, Tao F, Teixeira E, Timlin D, Waha K. 2014. How do various maize crop models vary in their responses to climate change factors? Glob. Change Biol. 20: $2301-2320$

Cane MA. 2005. The evolution of El Niño, past and future. Earth Planet. Sci. Lett. 230(3): 227-240.

Cane MA, Eshel G, Buckland RW. 1994. Forecasting Zimbabwean maize yield using eastern equatorial Pacific sea surface temperature. Nature 370: 204-205.

Challinor AJ, Wheeler TR, Slingo JM, Hemming D. 2005. Quantification of physical and biological uncertainty in the simulation of the yield of a tropical crop using present-day and doubled $\mathrm{CO}_{2}$ climates. Philos. Trans. R. Soc. B 360: 2085-2094.

Chang CP, Zhang Y, Li T. 2000a. Interannual and interdecadal variations of the East Asian summer monsoon and tropical Pacific SSTs. Part I: roles of the Subtropical Ridge. J. Clim. 13: 4310-4325.

Chang CP, Zhang Y, Li T. 2000b. Interannual and interdecadal variations of the East Asian summer monsoon and tropical Pacific SSTs. Part II: meridional Structure of the Monsoon. J. Clim. 13: 4326-4340.

Chen C, Lei C, Deng A, Qian C, Hoogmoed W, Zhang W. 2011. Will higher minimum temperatures increase corn production in Northeast China? An analysis of historical data over 1965-2008. Agric. For. Meteorol. 151: 1580-1588.

Chu PS. 2004. ENSO and tropical cyclone activity. In Hurricanes and Typhoons: Past, Present, and Potential, Murnane RJ, Liu KB (eds). Columbia University Press: Cambridge, UK, 297-332.

Deng XP, Shan L, Zhang H, Turner NC. 2006. Improving agricultural water use efficiency in arid and semiarid areas of China. Agric. Water Manage. 80(1): 23-40.

Diaz HF, Markgraf V. 2000. El Niño and the Southern Oscillation: Multiscale Variability and Global and Regional Impacts. Cambridge University Press: Cambridge, UK.

Dilley M, Heyman BN. 1995. ENSO and disaster: droughts, floods and El Niño/Southern Oscillation warm events. Disasters 19(3): 181-193. FAO. 1991. The Digitized Soil Map of the World (Release 1.0). 67/1. FAO: Rome.

FAO. 1992. Report on the Expert Consultation on Revision of FAO Methodologies for Crop Water Requirements. Land and Water Development Division, Food and Agriculture Organization, Rome.

Feng J, Li J. 2011. Influence of El Niño Modoki on spring rainfall over south China. J. Geophys. Res. 116: D13102.

Fischer RA. 1985. Number of kernels in wheat crops and the influence of solar-radiation and temperature. J. Agric. Sci. 105: 447-461.

Garcia AGY, Persson T, Paz JO, Fraisse C, Hoogenboom G. 2010. ENSO-based climate variability affects water use efficiency of rainfed cotton grown in the southeastern USA. Agric. Ecosyst. Environ. 139: $629-635$.

Gerten D, Schaphoff S, Haberlandt U, Lucht W, Sitch S. 2004. Terrestrial vegetation and water balance - hydrological evaluation of a dynamic global vegetation model. J. Hydrol. 286: 249-270.

Grassini P, Yang H, Irmak S, Thorburn J, Burr C, Cassman KG. 2011. High-yield irrigated maize in the Western US Corn Belt: II. Irrigation management and crop water productivity. Field Crop Res. 120(1): $133-141$.

Handler P. 1984. Corn yields in the United States and sea surface temperature anomalies in the equatorial pacific ocean during the period 1868-1982. Agric. For. Meteorol. 31: 25-32. 
Hansen JW, Hodges AW, Jones JW. 1998. ENSO influences on agriculture in the southeastern United States. J. Clim. 11: 404-411.

Hansen JW, Jones JW, Kiker CF, Hodges AW. 1999. El Niño-Southern Oscillation impacts on winter vegetable production in Florida. J. Clim. 12: $92-102$

Hansen JW, Challinor A, Ines A, Wheeler T, Moron V. 2006. Translating climate forecasts into agricultural terms: advances and challenges. Clim. Res. 33: 27-41.

Hetherington AM, Woodward FI. 2003. The role of stomata in sensing and driving environmental change. Nature 424(6951): 901-908.

Hsiang S, Meng K, Cane M. 2011. Civil conflicts are associated with the global climate. Nature 476: 438-441.

Huang R, Wu Y. 1989. The influence of ENSO on the summer climate change in China and its mechanism. Adv. Atmos. Sci. 6: 21-32.

Kenyon J, Hegerl GC. 2008. Influence of modes of climate variability on global temperature extremes. J. Clim. 21: 3872-3889.

Li Y, Barker R. 2004. Increasing water productivity for paddy irrigation in China. Paddy Water Environ. 2: 187-193.

Lima M, Marquet PA, Jaksic FM. 1999. El Niño events, precipitation patterns, and rodent outbreaks are statistically associated in semiarid Chile. Ecography 22: 213-218

Lin Y, Deng X, Jin Q. 2013. Economic effects of drought on agriculture in North China. Int. J. Disaster Risk Sci. 4(2): 59-67.

Liu Y, Ding Y. 1995. Reappraisal of the influence of ENSO events on seasonal precipitation and temperature in China. Sci. Atmos. Sin. 19(2): 200-208, (in Chinese).

Liu X, Herbert S, Jin J, Zhang Q, Wang G. 2004. Responses of photosynthetic rates and yield/quality of main crops to irrigation and manure application in the black soil area of Northeast China. Plant Soil 261(1-2): 55-60.

Lobell DB, Hammer GL, McLean G, Messina C, Roberts MJ, Schlenker W. 2013. The critical role of extreme heat for maize production in the United States. Nat. Clim. Change 3: 1-5.

Ludescher J, Gozolchiani A, Bogachev MI, Bunde A, Havlin S, Schellnhuber HJ. 2013. Improved el niño forecasting by cooperativity detection. Proc. Natl. Acad. Sci. 110(29): 11742-11745.

Mo X, Liua S, Lin Z, Xu Y, Xiang Y, McVicar TR. 2005. Prediction of crop yield, water consumption and water use efficiency with a SVAT-crop growth model using remotely sensed data on the North China Plain. Ecol. Model. 183(2): 301-322.

National Bureau of Statistics of China. 2013. China Statistical Yearbook 2012. China Statistics Press: Beijing.

Nicholls N. 1985. Towards the prediction of major Australian droughts. Aust. Meteorol. Mag. 33: 161-166.

Nielsen DC, Vigil MF, Benjamin JG. 2009. The variable response of dryland corn yield to soil water content at planting. Agric. Water Manage. 96(2): 330-336.

Paz JO, Woli P, Garcia y Garcia A, Hoogenboom G. 2012. Cotton yields as influenced by ENSO at different planting dates and spatial aggregation levels. Agric. Syst. 111: 45-52.

Phillips JG, Cane MA, Rosenzweig C. 1998. ENSO, seasonal rainfall patterns and simulated maize yield variability in Zimbabwe. Agric. For Meteorol. 90: 39-50.

Phillips J, Rajagopalan B, Cane M, Rosenzweig C. 1999. The role of ENSO in determining climate and maize yield variability in the US cornbelt. Int. J. Climatol. 19: 877-888.

Podestá GP, Messina CD, Grondona MO, Magrin GO. 1999. Associations between grain crop yields in Central-Eastern Argentina and El Niño-Southern Oscillation. J. Appl. Meteorol. 38: 1488-1498.

Poveda G, Álvarez DM, Rueda OA. 2011. Hydro-climatic variability over the Andes of Colombia associated with ENSO: a review of climatic processes and their impact on one of the Earth's most important biodiversity hotspots. Clim. Dyn. 36(11-12): 2233-2249.

Press WH, Teukolsky SA, Vetterling WT, Flannery BP. 1992. Numerical Recipes in FORTRAN: the Art of Scientific Computing, 2nd edn. Cambridge University Press: New York, NY, 107-110.

Qiu J, Tang H, Frolking S, Boles S, Li C, Xiao X, Liu J, Zhuang Y, Qin X. 2003. Mapping single-, double-, and triple-crop agriculture in China at $0.5^{\circ} \times 0.5^{\circ}$ by combining county-scale census data with a remote sensing-derived land cover map. Geocarto Int. 18(2): 3-13.

Ray JD, Gesch RW, Sinclair TR, Allen LH. 2002. The effect of vapor pressure deficit on maize transpiration response to a drying soil. Plant Soil 239(1): 113-121.

Ribaut JM, Betran J, Monneveux P, Setter T. 2009. Drought tolerance in maize. In Handbook of Maize: Its Biology, Bennetzen JL, Hake SC (eds). Springer: New York, NY, 311-344.
Royce FS, Fraisse CW, Baigorria GA. 2011. ENSO classification indices and summer crop yields in the Southeastern USA. Agric. For. Meteorol. 151: $817-826$.

Shahbaz K, Rana T, Cui Y, Blackwell J. 2006. Can irrigation be sustainable? Agric. Water Manage. 80: 87-99.

Shuai J, Zhang Z, Sun DZ, Tao F, Shi P. 2013. ENSO, climate variability, and crop yields in China. Clim. Res. 58: 133-148, doi: $10.3354 / \mathrm{cr} 01194$.

Sinclair TR, Tanner C, Bennett J. 1984. Water-use efficiency in crop production. Bioscience 34: 36-40.

Stein M. 1987. Large sample properties of simulations using Latin hypercube sampling. Technometrics 29(2): 143-151.

Sun DZ, Frank B. 2010. Climate Dynamics: Why Does Climate Vary? Geophysical Monograph Series, Vol. 189, 216 pp. AGU: Washington, DC, doi: 10.1029/GM189.

Sun X, Zhou H. 2008. Establishing eco-compensation system in China: practice, problems and strategies. China Popul. Resour. Environ. 18(5): $139-143$

Sun HY, Liu CM, Zhang XY, Shen YJ, Zhang YQ. 2006. Effects of irrigation on water balance, yield and WUE of winter wheat in the North China Plain. Agric. Water Manage. 85(1): 211-218.

Tack J, Ubilava D. 2013. The effect of El Niño Southern Oscillation on U.S. corn production and downside risk. Clim. Change 121: 689-700.

Tao F, Zhang Z. 2010. Adaptation of maize production to climate change in North China Plain: quantify the relative contributions of adaptation options. Eur. J. Agron. 33: 103-116.

Tao F, Yokozawa M, Hayashi Y, Lin E. 2003. Changes in agricultural water demands and soil moisture in China over the last half-century and their effects on agricultural production. Agric. For. Meteorol. 118: 251-261

Tao F, Yokozawa M, Zhang Z, Hayashi Y, Grassl H, Fu CB. 2004. Variability in climatology and agricultural production in China in association with the East Asian summer monsoon and El Niño Southern Oscillation. Clim. Res. 28: 23-30.

Tao F, Yokozawa M, Liu J, Zhang Z. 2008. Climate-crop yield relationships at provincial scales in China and the impacts of recent climate trends. Clim. Res. 38: 83-94.

Tao F, Yokozawa M, Zhang Z. 2009a. Modelling the impacts of weather and climate variability on crop productivity over a large area: a new process-based model development, optimization, and uncertainties analysis. Agric. For. Meteorol. 149: 831-850.

Tao F, Zhang Z, Liu J, Yokozawa M. 2009b. Modelling the impacts of weather and climate variability on crop productivity over a large area: a new super-ensemble-based probabilistic projection. Agric. For. Meteorol. 149: 1266-1278.

Thompson L. 1986. Climatic change, weather variability, and corn production. Agron. J. 78(4): 649-653.

Tong P. 1992. China Maize Planting Regionalization. China Agricultural Science and Technology Press: Beijing (in Chinese).

Wang B, Zhang Q. 2002. Pacific-East Asian teleconnection. Part II: how the Philippine Sea anomalous anticyclone is established during El Niño development. J. Clim. 15: 3252-3265.

Wang B, Wu R, Fu X. 2000. Pacific-east Asian teleconnection: how does ENSO affect east Asian climate? J. Clim. 13: 1517-1536.

Wu R, Kinter JL III. 2009. Analysis of the relationship of US droughts with SST and soil moisture: distinguishing the time scale of droughts. J. Clim. 22(17): 4520-4538.

Wu R, Hu ZZ, Kirtman BP. 2003. Evolution of ENSO-related rainfall anomalies in East Asia. J. Clim. 16: 3742-3758.

Yang K, Huang G, Tamai N. 2001. A hybrid model for estimating global solar radiation. Sol. Energy 70(1): 13-22.

Yang K, Koike T, Ye B. 2006. Improving estimation of hourly, daily, and monthly solar radiation by importing global data sets. Agric. For. Meteorol. 137(1): 43-55.

Zhang H, Wang X, You M, Liu C. 1999. Water-yield relations and water-use efficiency of winter wheat in the North China Plain. Irrig. Sci. 19(1): 37-45.

Zhang T, Zhu J, Yang X, Zhang X. 2008. Correlation changes between rice yields in North and Northwest China and ENSO from 1960 to 2004. Agric. For. Meteorol. 148: 1021-1033.

Zhu YM, Yang XQ, Chen XY, Zhao SS, Sun XG. 2007. Interdecadal variation of the relationship between ENSO and summer interannual climate variability in China. J. Trop. Meteorol. 13: 132-136.

Zobler L. 1986. A world soil file for global climate modelling. NASA Technical Memorandum 87802, NASA Goddard Institute for Space Studies, New York, NY, 32 pp. 